\title{
Competitive Profile Matrix of Selected Drug Stores at Jaen, Nueva Ecija, Philippines
}

\author{
Jennilyn C. Mina
}

Faculty Member, College of Management and Business Technology, Nueva Ecija University of Science and Technology-San Isidro Campus, Poblacion, San Isidro, Nueva Ecija 3106, Philippines

\begin{abstract}
To evaluate the Critical Success Factors and establish the Competitive Profile Matrix (CPM) of the drugstore business is the main objective of this study. This paper aims to critically appraise the importance of a company's competitive advantage and its role in formulating a company's strategy. It is a descriptive and conceptual analysis based on a literature review emphasizing strategic success tools such as Competitive Profile Matrix (CPM), for producing factors of achieving competitiveness in the fiercely competitive market. This research was conducted for three months from September 2019 to November 2019. The research method used was a descriptive approach using a scholarly-made questionnaire based on related literature and studies. The respondents of the study were the three (3) selected drug stores located at Jaen, Nueva Ecija, Philippines. Findings have shown that the drug store owner-respondents strongly agreed that products offer, financial strategy and location as strategic success factors. Furthermore, the respondents also agreed that company reputation, people or employee motivation and promotional strategy werealso factors for the company to be successful. 7. Company $B$ has the highest total when it comes to its Competitive Profile Matrix compare to Company A and $C$ because of the good location and company reputation.
\end{abstract}

Keywords - company, competitive profile matrix, critical success factors, drug store, retail business.

\section{INTRODUCTION}

As the population grows, the demand for medicine which is a necessity has continuously increased and that makes a drugstore business one of the most stable industries at the present time (Anlacan, 2012). Drugstores typically sell with the hope that they are providing the necessary medical, hygienic and health products and services to their customers delightfully. Customer expectations are difficult to meet (Taylor, 2019) and as competition offers plenty of options to the market, customer satisfaction becomes the core of any business, including community pharmacies (Satterfield, 2017).

Since medicine has become a daily essential, the demand for drugstore is growing and the potential of the pharmacy business becomes brighter than ever (Anlacan, 2013).According to Day and Wensley (1988), most drugstores were independent micro-businesses with strong local and occupational orientation. They also added that drugstores have their own specific qualities and featured values. According to Zentes, Morschett and Schramm-Klein
(2007), drugstores are one of the special stores in retail businesses. Operationally, for retail drugstores that are found in barrios, small towns or municipalities, differentiation should be measured relative to the competition which is meaningful in the assessment of competitive advantages.

On the rise competition and a rapidly changing environment have left many drugstore retailers a thorough search for avenues of survival. The turbulence in retailing is manifested by going-out-of-business sales, insolvencies and extrapolations of larger-scale failure (Zinn, 1990). To avoid such business situations, the business has to gain its competitive edge and this is the idea that has been adopted by the disciplines of marketing and strategic management as a passage too long-term advantage (Day and Wensley, 1998).

The emergence of the term competitive advantage came in the 1970s (David, 2012). The process of strategic management and the management of competitive advantage as specifically identifying, developing, and taking advantage of the regions through which a tangible and sustainable 
business edge can be achieved (South, 1980).Thus, diagnosing the inside and outside forces remain one of the vigorous tasks for every organization in their quest for survival. Organizations need to pay enough attention to strategy formulation, strategy implementation, and strategy evaluation (Burnes, 2009). Moreover, they must also engage in strategic management which is all about gaining and maintaining competitive advantage (David, 2011). The Competitive Profile Matrix (CPM) that identifies a firm's major competitors and its particular strengths and weaknesses in relation to a sample firm's strategic position (David, 2011) is a very useful tool in strategic management that is effective in formulating a more suited strategy. Hence, this study was performed to investigate and describe Critical Success Factors and determine the Competitive Profile Matrix (CPM) of the selected three (3) drug stores at Jaen, Nueva Ecija in the Philippines (Subia, Mangiduyos and Turgano, 2020).Specifically, it sought to describe the company's profile in terms of years in operations, types of ownership, number of branches and number of employees in the company. It is also intended to describe the strategic success factors of the company in terms of company reputation, product offering, people or employee motivation, promotional strategy and financial strategy. Lastly, it was conducted to determine the Competitive Profile Matrix of the drug stores.

\section{METHODOLOGY}

The study used a descriptive method of research in an attempt to analyze and interpret the company's profile, the strategic success factors and the competitive profile matrix of the three (3) drug stores at Jaen, Nueva Ecija, Philippines. As widely accepted, the descriptive method of research is a factfinding study that involves adequate and accurate interpretation of findings. Descriptive research describes a certain present condition (Creswell, 2014). Relatively, the method is appropriate to this study since descriptive research in this study was utilized to describe the profile of the company in terms of years in operations, types of ownership, number of branches and number of employees. Likewise, it was also used to determine the strategic success factors of the drug stores in terms of company reputation, product offering, people or employee motivation, promotional strategy and financial strategy. Moreover, it was utilized to determine the Competitive Profile Matrix (CPM) of particular drug stores.
The respondents of the study who were chosen purposively (Subia, 2018) were the owners/managers of the three (3) selected drug stores located at Jaen, Nueva Ecija, Philippines. Inclusion criteria were: a drug store that is operating for 5 years or more and is located in the aforementioned municipality. In order to collect the necessary data, the researcher utilized a scholarly-made questionnaire which was based on the reviewed literature and study related to the subject. The instrument is a structured questionnaire and is composed of close-ended questions that help to bring about information regarding the strategic success factors of the drug stores as rated by company owners/managers. The close-ended part of the questionnaire includes the profile of the company and the strategic success factors. In the strategic success factors, the rating scale of the close-ended questionnaire and the corresponding verbal description was presented on the table below:

Scale for Strategic Success Factors

\begin{tabular}{c|c|c}
\hline Scale & Range & Verbal Description \\
\hline 5 & $4.20-5.00$ & Strongly Agree \\
\hline 4 & $3.40-4.19$ & Agree \\
\hline 3 & $2.60-3.39$ & Neutral \\
\hline 2 & $1.80-2.59$ & Disagree \\
\hline 1 & $1.00-1.79$ & Strong Disagree \\
\hline
\end{tabular}

Appropriate statistical tools, such as frequency, percentage and weighted mean were used in this part of the study. Meanwhile, the Competitive Profile Matrix (CPM) which is also composed of the critical success factors including both internal and external issues of the drug storeswere developed by asking the owners/managers to assign to each factor a weight that ranges from 0.0 (not important) to 1.0 (very important). The weight indicates the relative importance of that factor to being successful in the firm's industry. On the other side of the coin, the ratings given by the owners/managers refer to strengths and weaknesses, where: 4 = major strength, $3=$ minor strength, $2=$ minor weaknesses, and 1 = major weaknesses (David, 2011). Lastly, the researcher has to multiply the weight by the rating for each factor to get a weighted score and then adds up each competitor's weighted scores to get a total weighted score. Data analysis was employed for the computations of the gathered information of the questionnaire from the respondents. 


\section{RESULTS AND DISCUSSION}

This section provides the presentation of data relevant to the problems stated above. Corresponding analysis and interpretation regarding some presented data were discussed using the above-mentioned statistical tools.

Table 1. Profile of the Company

\begin{tabular}{|l|c|c|c|}
\hline \multicolumn{1}{|c|}{ Profile of the Company } & Company A & Company B & Company C \\
\hline Years in Operation & 16 & 20 & 31 \\
\hline Types of Ownership & Sole Proprietorship & Sole Proprietorship & Sole Proprietorship \\
\hline Number of Branches & 1 & 1 & 2 \\
\hline Number of Employees in the Company & 6 & 4 & 9 \\
\hline
\end{tabular}

It can be seen from the data above that the three-drug stores are already operating for more than 15 years now which means that they have been in the industry now for quite a long time. The years of operations of any business have a great impact on their competitive advantages. It can also be noticed that all drug stores are under the sole proprietorship type of business. The advantage of the sole proprietorship type of business is the less paperwork requirement. Unlike corporations and partnerships, sole proprietors are not required to file any articles of incorporation, exhibit annual reports when they start businesses and the owner has complete control of the business (Woodruff, 2019).Among the three, there is only one drug store which has 2 branches and the rest only have one branch. The number of branches of the business is an important aspect of success for the reason that multiple storefronts increase sales opportunities (Nicasio, 2020). It is believed that every company's greatest asset is its employees and competitive success is achieved through them (Jassim and Jaber, 1998).

Table 2. Strategic Success Factors in terms of Company Reputation

\begin{tabular}{c|l|c|c}
\hline No. & \multicolumn{1}{|c|}{ Company Reputations } & Weighted Mean & Verbal Description \\
\hline 1. & Presence of good staff attraction and retention. & 4.67 & Strongly Agree \\
2. & Service-oriented when working with our customers. & 5.00 & Strongly Agree \\
3. & Good company image. & 5.00 & Strongly Agree \\
4. & Market share in the area. & 4.00 & Agree \\
5. & Number of existing branches in the province. & 2.00 & Disagree \\
6. & Engage in Corporate Social Responsibility. & 4.33 & Strongly Agree \\
\hline \multicolumn{2}{r|}{ Average Weighted Mean } & $\mathbf{4 . 1 7}$ & Agree \\
\hline
\end{tabular}

In various business markets, the company's reputation is a strong influence on the buying decisions of the consumers which may differ from the more specific product related influence of the brand's image (Cretu and Brodie 2007). The table above illustrates the strategic success factors of the three (3) drug stores in terms of company reputation. It can be gleaned from the table above that the owners strongly agreed that being service-oriented when working with customers is one of the factors to become successful. Scholars have long noted that the ability to attract and retain high-quality workers are critical to organizational competitiveness (Delery \& Shaw, 2001) and a stream of research in strategic Human Resource Management has examined the linkage between human resources practices, firm performance and effectiveness (Boselie, Dietz and Boon, 2005).

It is also proven from the data above that company image is one of the most important assets of an organization. It acts as a comfort factor for customers and assures them that they are buying from the best (Pamnani, 2016). On the contrary, the 
owners disagreed that the number of existing branches can be

contemplated as a factor for success.

Table 3. Strategic Success Factors in terms of Products Offering

\begin{tabular}{c|l|c|c}
\hline No. & \multicolumn{1}{|c|}{ Products Offering } & Weighted Mean & Verbal Description \\
\hline 1. & Breadth of the product range. & 3.67 & Agree \\
2. & Product quality and efficacy. & 4.33 & Strongly Agree \\
3. & Reasonable prices of the products. & 4.67 & Strongly Agree \\
4. & Availability of clinical data on the products supporting & 4.67 & Strongly Agree \\
& the claim. & 3.67 & Agree \\
5. & The products are largely homogeneous. & 4.67 & Strongly Agree \\
\hline \multicolumn{2}{r|}{ Average Weighted Mean } & $\mathbf{4 . 2 8}$ & Strongly Agree \\
\hline
\end{tabular}

It can be observed from the table above that the owners of the drug stores strongly agreed that the breadth of the product range is a factor for success. The breadth or width of the product refers to the number of different merchandise a retailer offers (Kotler, 2003). In the study of the state of the strategic management in the retail sector, it was found out that service, location and breadth or depth of merchandise were the most declared factors generating competitive advantage in the retail industry (Karemu, 1993). Similarly, the owner-respondents strongly agreed that product quality and efficacy is another factor for the company to be profitable. It is therefore assumed that product quality is positively related to the profitability of repeat purchases (Schmalensee, 1978). Likewise, the respondents strongly agreed that a reasonable price of the products is a factor that must be considered for the company in order for them to be sustainable. Dynamic pricing models update prices frequently, based on changing supply or demand characteristics (Nagle, Hogan and Zale 2010).

Equally, the owners strongly agreed that availability of clinical data on the products supporting the claim is a strategic success factor under products offering because of their ability to enable the development of new knowledge and to guide the increaseof best practices from the growing sum of individual clinical experiences, clinical data represent the resource most central to healthcare progress (Arrow, Bertko, Brownlee, Casalino and Cooper, 2009)

Table 4. Strategic Success Factors in terms of People or Employee Motivation

\begin{tabular}{c|l|c|c}
\hline No. & \multicolumn{1}{|c|}{ People or Employee Motivation } & Weighted Mean & Verbal Description \\
\hline 1. & Employees are paid in the above minimum wage. & 3.67 & Agree \\
2. & Employees are given just compensation. & 3.00 & Neutral \\
3. & Financial reward to employees is linked with their & 4.67 & Strongly Agree \\
& performance. & 4.67 & Strongly Agree \\
4. & Well trained and highly effective sales force. & 4.33 & Strongly Agree \\
5. & Field force personnel are getting recognition rewards. & 4.33 & Strongly Agree \\
6. & Positive work ambiance. & $\mathbf{4 . 1 1}$ & Agree \\
\hline \multicolumn{2}{r|}{ Average Weighted Mean }
\end{tabular}

It can be perceived from the table above that the owners of three (3) drug stores strongly agreed that financial reward to employees is linked with their performance. It is essential that good employment practices have been placed on strategies to retain staff and link satisfaction and commitment to retention (Beauregard and Henry, 2009). Likewise, the manager-respondents strongly agreed that well-trained and highly effective sales force is a factor for 
the company to be successful. According to French and Raven (1959), salesperson expertise builds buyer trust by increasing the buyer's confidence that he can provide a valuable solution and deliver on-premises. Also, salespersonsare proven to be effective if they can enhance their interests (Subia, 2020) of their buyers.

By the same token, the owners strongly agreed that field force personnel getting recognition awards is a strategic success factor in boosting their employee morale. Erickson and Gratton (2007) mentioned that in the war for talent, organizations won't become noble employers merely by employingother companies' best practices but rather need to deliver a signature experience to nurture a dedicated organizational workforce. In the same way, the ownerrespondents strongly agreed that positive work ambiance is a factor of success that's why organizations also need to provide a positive workplace experience to attract and retain employees (Boxall and Macky, 2009)

Table 5. Strategic Success Factors in terms of Promotional Strategy

\begin{tabular}{|c|c|c|c|}
\hline No. & Promotional Strategy & Weighted Mean & Verbal Description \\
\hline 1. & $\begin{array}{l}\text { Presence of significant campaign using the } \\
\text { advertisement. }\end{array}$ & 3.33 & Neutral \\
\hline 2. & The sales promotion is through personal selling. & 4.33 & Strongly Agree \\
\hline 3. & The company develops a value proposition. & 4.33 & Strongly Agree \\
\hline 4. & Drugstore flyers contain the price of the products. & 3.33 & Neutral \\
\hline 5. & Word of mouth of customers to another customer. & 4.67 & Strongly Agree \\
\hline 6. & It offers customer loyalty. & 3.00 & Neutral \\
\hline \multicolumn{2}{|r|}{ Average Weighted Mean } & 3.83 & Agree \\
\hline
\end{tabular}

It can be observed from the table above that the owners strongly agreed that when the sales promotion is through personal selling it is a factor for success. Mercer (1996) mentioned that the best form of promotion is the conversation that takes place between the salesperson and his customer because it is interactive and conversation is specific to the needs of both.

Correspondingly, the owner-respondents strongly agreed that it is also a success factor when the company develops a value proposition. Congruently, they also mentioned that they strongly agreed that word of mouth of the customer to another customer is a major contributor to the success of the company. Recent research suggests consumers value exclusive promotions over inclusive ones (Barone and Roy, 2010) and it was suggested that exclusive promotions have the greatest appeal to consumers who adopt an independent rather than collectivist self-construal.

The owners/managers were neutral in terms of the presence of a significant campaign using advertisement as a factor for the company to be successful. They were also neutral on the idea that drugstore flyers contain the price of the products as a factor to be successful in the industry.

Table 6. Strategic Success Factors in terms of Financial Strategy

\begin{tabular}{c|l|c|c}
\hline No. & \multicolumn{1}{|c|}{ Financial Strategy } & Weighted Mean & Verbal Description \\
\hline 1. & The company is perceived as financially stable. & 4.67 & Strongly Agree \\
2. & The company offers credit transactions to distributors. & 4.33 & Strongly Agree \\
3. & The company extends credit to major customers. & 4.33 & Strongly Agree \\
4. & The company offers discounts to loyal customers. & 4.67 & Strongly Agree \\
5. & The company gives sales discounts to bulk purchases. & 4.67 & Strongly Agree \\
6. & The company allocates resources wisely. & 4.67 & Strongly Agree \\
\hline \multicolumn{2}{r|}{ Average Weighted Mean } & $\mathbf{4 . 5 6}$ & Strongly Agree \\
\hline
\end{tabular}


It can be observed from the table above that the owners strongly agreed that it is a factor for success if the company is perceived as financially stable by the customers same is true when the company offers credit transactions to distributors. Likewise, the respondents strongly agreed that it is a success factor when the company extends credit to major customers. In the same way, the respondents strongly agreed that it is a success factor when the company offers discounts to loyal customers. Grewal, Hardestyand Iyer (2004) show in a scenario-based study that respondents indicate more trust and fairness if customers who buy more frequently receive lower prices, rather than new customers and thus create customer loyalty.

Just asthe respondents strongly agreed that it is a success factor when the company gives sales discounts to bulk purchases. Conditional promotions are another type of promotion where some condition has to be met for the consumer to avail of the discount. Lee and Ariely (2006) examined the effectiveness of conditional promotions where the condition is under the control of the consumer and find that these promotions are most effective when consumers have less concrete shopping goals.

Table 7. Strategic Success Factors in terms of Location

\begin{tabular}{|c|c|c|c|}
\hline No. & Location & Weighted Mean & Verbal Description \\
\hline 1. & The location is accessible for distributors and customers & 5.00 & Strongly Agree \\
\hline 2. & The location has security measures that keep the premises safe. & 4.67 & Strongly Agree \\
\hline 3. & $\begin{array}{l}\text { The area already has a ripe market that could be the ideal way to pick } \\
\text { up customers very quickly and establish a presence in a new area in a } \\
\text { relatively short time frame. }\end{array}$ & 5.00 & Strongly Agree \\
\hline 4. & $\begin{array}{l}\text { The company premises are able to accommodate business growth or a } \\
\text { spike in demand. }\end{array}$ & 4.67 & Strongly Agree \\
\hline 5. & The location has a good road network, constant power supply, etc. & 5.00 & Strongly Agree \\
\hline 6. & The location is near to a hospital. & 4.00 & Agree \\
\hline \multicolumn{2}{|r|}{ Average Weighted Mean } & 4.72 & Strongly Agree \\
\hline
\end{tabular}

It can be observed that all the respondents strongly agreed that when the location is accessible for distributors and customers, the location has security measures that keep the premises safe, the area already has a ripe market that could be the ideal way to pick up customers very quickly and establish a presence in a new area in a relatively short time frame, the company premises are able to accommodate business growth or a spike in demand and the location has good road network, constant power supply, etc. these are all major contributors for the company to be successful. On the other hand, it has been agreed by the respondents that the proximity to the hospital of the location of a drug store is a factor for success.Location is inclined by the target market and the availability of resources. Although a prime location is not an assurance for success, a poor location strategy certainly leads to failure (Njoroge, 2008).

Table 8. Competitive Profile Matrix of Drug Stores

\begin{tabular}{|l|c|c|c|c|c|c|c|c|c|}
\hline \multirow{2}{*}{$\begin{array}{c}\text { Critical Success } \\
\text { Factor }\end{array}$} & \multicolumn{3}{c|}{ Company A } & \multicolumn{3}{c|}{ Company B } & \multicolumn{3}{c|}{ Company C } \\
\cline { 2 - 11 } & Weight & Rating & Score & Weight & Rating & Score & Weight & Rating & Score \\
\hline Company reputation & 0.15 & 2 & 0.30 & 0.20 & 4 & 0.80 & 0.15 & 2 & 0.30 \\
\hline Products offering & 0.15 & 2 & 0.30 & 0.15 & 3 & 0.45 & 0.20 & 3 & 0.60 \\
\hline Employee motivation & 0.10 & 1 & 0.10 & 0.15 & 3 & 0.45 & 0.15 & 2 & 0.30 \\
\hline Promotional strategy & 0.10 & 1 & 0.10 & 0.15 & 3 & 0.45 & 0.05 & 1 & 0.05 \\
\hline Financial strategy & 0.30 & 4 & 1.20 & 0.10 & 2 & 0.20 & 0.20 & 3 & 0.60 \\
\hline
\end{tabular}




\begin{tabular}{|l|l|l|l|l|l|l|l|l|l|}
\hline Location & 0.20 & 3 & 0.60 & 0.25 & 4 & 1.00 & 0.25 & 4 & 1.00 \\
\hline Total & $\mathbf{1 . 0 0}$ & & $\mathbf{2 . 6 0}$ & $\mathbf{1 . 0 0}$ & & $\mathbf{3 . 3 5}$ & $\mathbf{1 . 0 0}$ & & $\mathbf{2 . 8 5}$ \\
\hline
\end{tabular}

It can be gleaned from the data above that Company B has the highest total score. The Competitive Profile Matrix (CPM) displays the basis of an organization's strategy and is a useful instrument to communicate those strategic attributes to all in the organization (Bygrave and Zacharakis, 2010). It is very apparent from the data above that Company B believes that location and company reputation are the two most competitive advantages they have over the other drug stores in the same municipality and they believe that these two are their major strengths. Location isperhaps the most important factor because ones a location decision is made, it is expensive to change (Cox and Brittan, 2000).

Since the CPM features each Critical Success Factors (CSF) and displays the organizations' strengths and weaknesses in the significantly important areas of business, it is a tool that businesses should adopt. Analyzing the organization in this manner is an effective way to evaluate many competitors in one framework to support an effective strategic plan (Fleisher and Bensoussan, 2003). This strategic tool is very beneficial in analyzing the company's position in the market thus giving the owner the baseline in working for the best game plan to have its competitive edge over its competitors.

\section{CONCLUSIONS AND RECOMMENDATIONS}

Based on the findings of this study, it can be concluded that the drug store business is one of the most profitable in this era as medicine becomes an essential product for the consumers. However, just like every retail business, the drug store industry must also give attention to the factors that could contribute to their success. It is important that they know the strengths they have to sustain and the weaknesses they have to polish in order to satisfy their customers.

It is therefore suggested by the researcher that the drugstore companies should focus more on improving and acquiring competencies on the identified critical success factors as this will enable to improve their competitive position, emphasizing on the location of the drugstore business as it gets the highest weighted score in the established Competitive Profile Matrix (CPM).It is also recommended that market research should continuously be conducted regularly with the intent of establishing what factors would influence success in business in order to give them intensive consideration.The senior management of the drugstore companies must constantly assess their critical success factors and Competitive Profile Matrix (CPM) as the foundation, so as to respond to the changes in the operating environment and clearly understand which ones have emerged as a result of this and address them as necessary.Lastly, the goal of these companies should be to design a strategy aimed at stacking up well on all of the industry's future success factors and be distinctively better than competition on one or possibly more of the critical success factors. This can be a route to have above-average profits in the industry.

\section{REFERENCES}

[1] Anlacan, Ruben Jr. (2012). Starting a Drugstore Business in the Philippines. Retrieved on December 02, 2019, from http://www.businesscoachphil.com/starting-a-drugstorebusiness-in-the-philippines

[2] Anlacan, Ruben Jr. (2013). Putting Up A Drugstore In The Philippines. Retrieved on December 02, 2019, from http://www.businesscoachphil.com/putting-up-a-drugstorein-the-philippines

[3] Arrow. K., Bertko, J.,Brownlee, S., Casalino, L. P., Cooper, J., et al., (2009) WPMM. Toward a $21^{\text {st }}$-century health care system: Recommendations for health care reform. Annals of Internal Medicine. 150 (7): 493-495. [PubMed]

[4] Barone, M. and Roy, T. (2010). Does Exclusivity Always Pay Off?Exclusive Price Promotions andConsumer Response. Journal of Marketing, Vol. 74, pp. 121-132ISSN: 0022-2429

[5] Beauregard, T.A. and Henry, L.C. (2009). Making the Link between Work-life Balance Practices and Organizational Performance. Human Resource Management Review 19(1): 9-22.

[6] Boselie, P. Dietz, G. and Boon, C. (2005). Commonalities and contradictions in HRM and performance research. Human Resource Management Journal 15(3): 67-94

[7] Boxall, P. and Macky, K. (2009). Research and Theory on High-Performance Work Systems: Progressing the High Involvement System. Human Resource Management Journal 19(1): 3-23.

[8] Burnes, B. (2009). Managing Change: A Strategic Approach to Organizational Dynamic (5th Ed). Harlow: FT Prentice Hall

[9] Bygrave, W.D. and Zacharakis, A. (2010). Entrepreneurship, John Wiley and Sons, New Jersey.

[10] Cox, R. and Brittan, P. (2000).Retail Management. Fourth edition. Financial Times:Prentice. Hall. 
[11] Creswell, J. W. (2014). Research Design: Qualitative, Quantitative and Mixed Methods Approaches (4th Ed.). Thousand Oaks, CA: Sage Publications Ltd.

[12] Cretu, A. and Brodie, R. (2007). The Influence of Brand Image and Company Reputation Where Manufacturers Market to Small Firms: A Customer Value Perspective

[13] David, F. R. (2011).Strategic Management Concepts and Cases: A Competitive Advantage Approach (13th Ed). New Jersey: Pearson Education Prentice Hall.

[14] Day, G. and Wenley R., (1988). Assessing Advantage: A Framework for Diagnosing Competitive Superiority, Journal of Marketing, 52, pp. 1-20

[15] Delery, J. and Shaw, J. (2001). The Strategic Management of People in Work Organizations: Review, Synthesis and Extension. Research in Personnel and Human Resource Management 20: 165-97.

[16] Erickson, T.J. and Gratton, L. (2007). What it Mean to Work Here? Harvard Business Review 85(3): 104-12.

[17] Fleisher, C.S., and Bensoussan, B. (2003). Strategic and Competitive Analysis: Methods and Techniques for Analyzing Business Competition. Upper Saddle River, NJ: Prentice Hall.

[18] French, J. and Raven, B.(1959). The Bases of Social Power. University of Michigan

[19] Grewal, D., Baker, J., Levy, M. and Voss, G. (2003). The Effects of Wait Expectations and Store Atmosphere Evaluations on Patronage Intentions in Service-Intensive Reatil Stores. Journal of Retailing, Vol. 79, Issue 4, 259-268

[20] Grewal, D., Hardesty, D. and Iyer, G. (2004). The Effects of Buyer Identification and Purchase Timing on Consumers' Perceptions of Trust, Price Fairness, and Repurchase Intentions. Journal of Interactive Marketing, 18 (4), 87-100.

[21] Jassim, R. K., and Jaber, G. (1998) Competitive Advantage through the Employees. Research Paper, University of Auckland, New Zealand

[22] Karemu, C. (1993). "The State of Strategic Management Practices in the Retailing

a. Sector: The Case of Supermarkets in Nairobi". Unpublished MBA Project, University of Nairobi

[23] Kotler, J. (2003). Marketing Management: Selling the Product and Branding Strategy. Upper Saddle River New Jersey: Prentice Hall, pp. 406-442

[24] Mercer, D. (1996), Marketing, 2nd.ed., Blackwell, Oxford

[25] Nagle, Thomas T., John E. Hogan and Joseph Zale (2010), The Strategy and Tactics of Pricing: A Guide to Growing More Profitably, 5th ed. Upper Saddle River, NJ: Prentice Hall.

[26] Nicasio, Francesca (2020). How to Increase Sales in Retail: 17 Expert-Backed Tips to Try in Your Store. Retrieved on February 20, 2020 from: https://www.vendhq.com/blog/howto-increase-sales-retail/
[27] Njoroge, E. (2008). A Survey of the Key Success Factors for Pharmaceutical Retail Business in the Nairobi Central Business District

[28] Pamnani, H. (2016). Article. Businessworld: Importance of Corporate Image

[29] South, Stephen E., (1980). Competitive Advantage: The Cornerstone of Strategic Thingking, The Journal of Business Strategy, pp. 15-25

[30] Satterfield, Paul (2017). Seven Ways to Exceed Patient Expectations and Increase Customer Satisfaction. Retrieved on November 11, 2019 from: https://www.amerisourcebergen.com/insights/pharmacies/sev en-ways-to-exceed-patient-expectations-and-increasecustomer-satisfaction

[31] Schmalensee, Richard (1978). A Model of Advertising and Product Quality. Journal of Political Economy, Vol. 86, Issue 3, 485-503

[32] Subia, G.S. (2018) Comprehensible Technique in Solving Consecutive Number Problems in Algebra. Journal of Applied Mathematics and Physics, 6, 447457.https://doi.org/10.4236/jamp.2018.63041

[33] Subia, G. S., Mangiduyos, G. P., \& Turgano, J. B. D. (2020).Emergency Preparedness of Novo Ecijanos. Open Journal of Social Sciences, 8, 17-23. https://doi.org/10.4236/jss.2020.83003

[34] Subia, G. S. (2020). Fortuitous: A proposed activity-based book in mathematics of chance. International Journal of Scientific and Technology Research, 9(3), 450-453.

[35] Taylor, Mark (2019). Customer Expectations: How to Meet (and Exceed) Expectations. Retrieved on November 27, 2019 from: https://www.superoffice.com/blog/exceed-customerexpectations-2014/

[36] Woodruff, Jim (2019. Five Advantages of a Sole Proprietorship. Retrieved on January 14, 2020 from: https://smallbusiness.chron.com/five-advantages-soleproprietorship-22896.html

[37] Zentes, J., Morschett, D., \& Schramm-Klein, H. (2007). Strategic Retail Management: Text and International Cases. Wiesbaden: Gabler.

[38] Zinn, Laura (1990). Retailing: Who Will Survive? Business Week, pp. 134-144 